\title{
Roger Pierrot, L'édition de la correspondance de Balzac
}

\section{Marco Stupazzonl}

\section{(2) OpenEdition}

\section{Journals}

\section{Edizione digitale}

URL: http://journals.openedition.org/studifrancesi/34872

DOI: 10.4000/studifrancesi.34872

ISSN: 2427-5856

\section{Editore}

Rosenberg \& Sellier

\section{Edizione cartacea}

Data di pubblicazione: 1 novembre 2005

Paginazione: 431

ISSN: 0039-2944

\section{Notizia bibliografica digitale}

Marco Stupazzonl, «Roger Pierrot, L'édition de la correspondance de Balzac», Studi Francesi [Online], 146 (XLIX | II) | 2005, online dal 30 novembre 2015, consultato il 19 avril 2021. URL: http://

journals.openedition.org/studifrancesi/34872 ; DOI: https://doi.org/10.4000/studifrancesi.34872

\section{Questo documento è stato generato automaticamente il 19 avril 2021.}

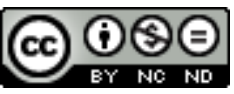

Studi Francesi è distribuita con Licenza Creative Commons Attribuzione - Non commerciale - Non opere derivate 4.0 Internazionale. 


\title{
Roger Pierrot, L'édition de la correspondance de Balzac
}

\author{
Marco Stupazzonl
}

\section{NOTIZIA}

ROGER PIERROT, L'édition de la correspondance de Balzac, «Revue d'Histoire Littéraire de la France», 103e année, $n^{\circ} 2$, avril-juin 2003, pp. 375-376.

1 In questa breve nota, Roger Pierrot presenta alcune tra le fondamentali linee-guida programmatiche e metodologiche che informano l'impianto della nuova edizione multimediale (rivista, integrata e corretta rispetto all'edizione cartacea del 1960-1962) della Correspondance di Balzac, di cui è ormai prossima l'uscita del primo Cd-Rom per gli anni 1809-1835. Il piano di lavoro di questa nuova e attesa 'impresa' culturale si fonda sulla ricerca e sulla catalogazione, sulla base del più modemi e rigorosi strumenti dell'emdizione contemporanea, degli autografi conservati, scrive Pierrot, «dans des fonds publics, dans des archives privés ou circulant dans le commerce» (p. 375).

2 I quasi 1200 documenti che formeranno il primo tassello di questa nuova edizione della corrispondenza balzachiana comprendono altresì un numero rilevante di lettere indirizzate allo scrittore «par des femmes, des artistes, des gens d'affaires ou du monde» (p. 376). 